słuchaczy z architekturą szkół w Kowlu na Wołyniu w okresie międzywojennym (1921-1939). Po wysłuchaniu wszystkich wystąpień odbyła się dyskusja, podczas której podjęto kwestie przedstawione we wszystkich referatach. Największe zainteresowanie wzbudził temat dworców kolejowych.

Podsumowując IV Kongres, należy pochwalić organizatorów za realizację tak dużego i trudnego przedsięwzięcia. Udało im się zgromadzić naukowców z wielu dziedzin i krajów, którzy przygotowali wystąpienia o dawnej RP na wysokim poziomie, same zaś obrady trwały aż trzy dni. Wzorem lat ubiegłych jest planowane wydanie wszystkich tekstów wystąpień, co bez wątpienia przełoży się na zwiększenie wiedzy o wielokulturowym dziedzictwie dawnej RP.

Mariusz Balcerek (Toruń)

ORCID: 0000-0002-1007-8042

\title{
Sprawozdanie z konferencji „Błędy w dawnej medycynie i historiografii lecznictua”, Wrocław, 1 XII 2018
}

\footnotetext{
7 początkiem grudnia 2018 roku w Instytucie Historycznym UUniwersytetu Wrocławskiego odbyła się już trzecia z rzędu konferencja poświęcona historii zdrowotności i stanu zdrowia społeczeństw w przeszłości. Organizatorzy konferencji (dr Katarzyna Pękacka-Falkowska, dr Danuta Raj, dr Jakub Węglorz), wywodzący się z trzech różnych ośrodków o zróżnicowanym profilu badawczym, podjęli współpracę mającą na celu zachęcenie
} 
do wspólnych obrad przedstawicieli różnych nauk zajmujących się historią zdrowotności. Poprzednie edycje konferencji dotyczyły metodologii badań nad historią zdrowotności (Zdrowie, choroba i lecznictwo jako pole badań nad przesztościa - aktualne metody, zagadnienia i problemy, Wrocław, 17 XI 2016 r.) oraz problemów dawnej diagnostyki i lecznictwa (Historyczne koncepcje choroby, podstawy diagnozowania dysfunkcji organizmu, Wrocław, 29 IX 2017 r.). Interdyscyplinarny charakter tematyki wrocławskich spotkań pozwala na zaproszenie badaczy działających nie tylko na polu humanistyki, ale i nauk przyrodniczych, w szczególności biologiczno-medycznych. Dzięki zróżnicowanym specjalizacjom uczestnicy konferencji mogą spojrzeć na analizowaną tematykę z różnych perspektyw, co znacznie wzbogaca dyskusję nad prezentowanymi problemami badawczymi.

W tym roku skoncentrowano się na zagadnieniu błędu w dawnej medycynie i historiografii lecznictwa. Zamierzeniem organizatorów było nie tylko skupienie się na mylnych diagnozach osób parających się medycyną (np. lekarzy, aptekarzy, chirurgów), ale także zwrócenie uwagi na błędne koncepcje funkcjonujące w przeszłości, a obecnie rozpatrywane jako słuszne, lub na teorie, które dawniej cieszyły się dużym poszanowaniem, a następnie uznano je za nieprawdziwe. Organizatorzy pragnęli także pochylić się nad chybionymi interpretacjami współczesnych badaczy historii medycyny i lecznictwa oraz nad samym rozwojem medycyny na przestrzeni stuleci.

Panel otwierający konferencję poprowadził dr hab. Tomasz Wiślicz, prof. IH PAN (Instytut Historii im. Tadeusza Manteuffla PAN), który moderował zagadnienia oscylujące wokół błędnych diagnoz w dawnych metodach leczenia poszczególnych chorób. Pierwszy referat, poświęcony bezpłodności, został wygłoszony przez dr hab. Anną Odrzywolską-Kidawę, prof. UJD (Akademia im. Jana Długosza w Częstochowie). Bazując na zielnikach i poradnikach gospodarczych, ukazała sposoby leczenia i radzenia sobie z bezpłodnością w XVI i XVII wieku. Co ciekawe, obok przepisów zielarskich za remedia uważano wiele magicznych praktyk i ceremoniałów, które rzekomo miały pomóc w zdobyciu potomstwa. Odmienne zagadnienie, choć wciąż opierające się na mylnych praktykach, przedstawiła dr Katarzyna Pękacka-Falkowska (Uniwersytet Medyczny im. K. Marcinkowskiego w Poznaniu), która zanalizowała - na podstawie akt sądowych - 
problematykę hydrostatycznej próby płucnej w osiemnastowiecznych Prusach Królewskich. Referat zamykający panel został wygłoszony przez dr Elżbietę Nowosielską (Instytut Historii im. Tadeusza Manteuffla PAN), która omówiła metody diagnozowania i leczenia „chorych na głowę” w siedemnasto- i osiemnastowiecznej Rzeczypospolitej. Autorka w szczególności skupiła się na melancholii i jej postrzeganiu w okresie staropolskim.

Druga część obrad była prowadzona przez prof. dr hab. Bożenę Płonkę-Syrokę (Uniwersytet Medyczny im. Piastów Śląskich we Wrocławiu). Pierwszy referat wygłosiła dr Danuta Raj (Uniwersytet Medyczny im. Piastów Śląskich we Wrocławiu), która w swym wystąpieniu skupiła się na działaniach terapeutycznymi leków wczesnonowożytnych. Fundamentem referatu było ukazanie rozbieżności między oczekiwanymi efektami a możliwościami leczniczymi specyfików. Z kolei dr Piotr Paluchowski (Gdański Uniwersytet Medyczny), bazując na gdańskich kalendarzach z XVIII wieku, omówił zagadnienie astromedycyny, zwłaszcza w kontekście wpływu astrologii na zdrowie człowieka.

Trzeci panel moderował prof. dr hab. Jaromir Jeszke (Uniwersytet im. A. Mickiewicza w Poznaniu). Pierwsze wystąpienie zaprezentowane przez dr. hab. Tomasza Wiślicza, prof. IH PAN zostało poświęcone ludowym sposobom radzenia sobie z chorobami. Obok analizy skuteczności tradycyjnych metod leczniczych w kręgach chłopskich, prof. Wiślicz podkreślił konieczność rozwoju i eksploracji metod badawczych w prowadzeniu badań nad medycyną ludową w minionych wiekach. Wątek ukazujący stan wiedzy medycznej społeczności wiejskiej kontynuowała mgr Joanna Schmidt (Uniwersytet w Białymstoku), która bazując na Księgach Zmarłych parafii rzymskokatolickich z południowego Podlasia w latach 1818-1827, ukazała m.in. główne przyczyny śmierci występujące we wsiach objętych analizą. Panel został zamknięty referatem mgr Karoliny Wojtuckiej (Uniwersytet Wrocławski), w którym omówiono wybrane przypadki oskarżeń o czary. Prelegentka zwróciła uwagę na sytuację akuszerek i wiejskich znachorek, które w przypadku mylnych diagnoz i braku powodzenia w leczeniu mogły spotkać się z oskarżeniami o korzystanie z magii.

Trzeci panel zakończył pierwszy etap obrad, które kontynuowano po przerwie obiadowej. Czwarta, przedostatnia część konferencji, prowadzona przez dr Katarzynę Pękacką-Falkowską, została poświęcona zagad- 
nieniom historiograficznym oraz metodycznym. Dr Maciej Włodarczyk (Uniwersytet Medyczny we Wrocławiu) ocenił źródła błędów w chemii i ich skutki w rozwoju współczesnej medycyny. Omówił rolę mediów i naukowców w rozpowszechnianiu, utrwalaniu i rozwijaniu błędów, a także ukazał sposoby wychwytywania i korygowania omyłek. Na podstawie kilku przedstawionych sytuacji zaprezentował także skutki nieprawidłowych procedur. Zagadnienie błędów popełnianych w medycynie kontynuowała dr Joanna Nieznanowska (Pomorski Uniwersytet Medyczny w Szczecinie), która wygłosiła referat poświęcony błędom występującym w historiografii medycznej. Referentka poruszyła również kwestię sposobu przedstawienia w polskich podręcznikach do historii medycyny błędnych teorii i praktyk. Ważnym wątkiem było ukazanie wpływu Kościoła przedreformacyjnego oraz Kościołów po reformacji na rozwój medycyny i chirurgii oraz ich postrzegania. Temat zamykający czwarty panel został przedstawiony przez $\mathrm{dr}$. Ryszarda Kacałę (Uniwersytet Medyczny im. Piastów Śląskich we Wrocławiu). Omawiając przeprowadzane w czasach nam współczesnych zabiegi na otwartym sercu, prelegent wskazał na błędy popełniane podczas pierwszych transplantacji organów oraz na to, jak szereg procedur ma wpływ na efektywność (lub jej brak) danej operacji.

Ostatni panel konferencji, którego moderatorem był prof. dr hab. Bogdan Rok (Uniwersytet Wrocławski), składał się z trzech wystąpień: dr. Rafała Szmytki (Uniwersytet Jagielloński), dr. Radosława Łazarza (Akademia Sztuk Teatralnych im. St. Wyspiańskiego w Krakowie) oraz dr. Jakuba Węglorza (Uniwersytet Wrocławski). Pierwszy referat poświęcono hipotezom o przyczynach śmierci Henryka II Walezego na podstawie ryciny Quarante tableaux autorstwa Jeana Perrssina i Jacques'a Tortorela. Wykorzystując ten materiał źródłowy, dr Szmytka rozważał opinię autorów jednego z przekazów ikonograficznych na temat śmierci króla: czy nastąpiła ona w konsekwencji popełnionego błędu lekarzy, czy też była nieuniknioną konsekwencją wypadku. W ciekawy sposób autor wystąpienia przeanalizował także warstwę symboliczną otoczenia króla w momencie jego śmierci. Kolejne wystąpienie, zatytułowane Krojenie organicznej metafory państwa, zostało wygłoszone przez dr. Radosława Łazarza. Poruszając zagadnienie anatomii i jej rozwoju na przestrzeni wieków, prelegent metaforycznie odniósł się do koncepcji politycznych, w których hasło „ciało” używane jest 
w rozmaitych kontekstach (ciało króla, ciało państwo, ciało rzeczypospolitej). Istotnym elementem wystąpienia było ukazanie, jak w XVI wieku nastąpił gwałtowny rozwój terminologii związanej z cielesnością, ale także i ze śmiercią, co mogło mieć wpływ na zmiany w politycznym postrzeganiu ciała przez wybrane kręgi społeczne. Obrady zamykał dr Jakub Węglorz z referatem poświęconym zagadnieniu recepcji medycyny humoralnej z perspektywy aktualnego paradygmatu medycznego. Prelegent zwrócił uwagę na problemy współczesnego oceniania lecznictwa w przeszłości. Podkreślił, jak bardzo istotne jest uwzględnienie kontekstu, poglądów i wiedzy z poprzednich stuleci, gdyż ich pominięcie może mieć wpływ na błędne rozumienie historii.

Organizatorom zależało na tym, aby - obok wygłaszanych referatów - dużo czasu poświęcić na dyskusję, dzięki której dogłębniej można było przeanalizować prezentowaną problematykę. Stąd każdy z prelegentów starał się zwięźle zarysować najważniejsze problemy związane z prezentowanym zagadnieniem, by następnie wspólnie omówić możliwe interpretacje podczas rozbudowanych sekcji poświęconych wymianie przemyśleń i uwag. Dzięki takiemu charakterowi konferencji oprócz uczestników z referatami aktywny udział w obradach mogli wziąć także pozostali goście. Powstała w ten sposób wspólna platforma umożliwiła konstruktywną wymianę doświadczeń i ułatwiła rozwiązywanie problemów pojawiających się na styku obu dyscyplin: historii i medycyny. Przyjęta pozytywnie forma konferencji oraz wciąż szeroki wachlarz zagadnień do przedyskutowania pozwalają na kontynuowanie wrocławskich spotkań dotyczących historii lecznictwa także w nadchodzących latach. 